JURNAL BASICEDU

Research \& Learning in Elementary Education

https://jbasic.org/index.php/basicedu

\title{
PENERAPAN MODEL CREATIVE PROBLEM SOLVING (CPS) UNTUK MENINGKATKAN KEMAMPUAN BERPIKIR KREATIF MATEMATIS SISWA SEKOLAH DASAR
}

\author{
Anggy Giri Prawiyogi ${ }^{1}$, Sri Wulan Anggraeni ${ }^{2}$, Teten Ginanjar Rahayu ${ }^{3}$ \\ Universitas Buana Perjuangan Karawang, Jawa Barat, Indonesia ${ }^{1,2,3}$ \\ Email: Anggy.Prawiyogi@ubpkarawang.ac.id ${ }^{1}$, wulan.anggraeni@ubpkarawang.ac.id ${ }^{2}$, \\ teten.ginanjar.r@student.upi.edu ${ }^{3}$
}

\begin{abstract}
Abstrak
Permasalahan dalam pelajaran matematika siswa kurang tertarik terhadap pelajaran matematika karena matematika dianggap sebagai pelajaran yang paling sulit diantara pelajaran yang lainnya serta lemahnya kemampuan berpikir kreatif siswa dalam memecahkan masalah matematika. Penelitian ini bertujuan untuk mengetahui pengaruh penggunaan model CREATIVE PROBLEM SOLVING (CPS) terhadap kemampuan berpikir kreatif matematis siswa kelas IV di SDIT Cendekia Kecamatan Purwakarta Kabupaten Purwakarta. Desain penelitian yang digunakan adalah Penelitiam Tindakan Kelas desain yang lebih dikenal dengan sistem spiral refleksi diri yang dimulai dari rencana, tindakan, pengamatan refleksi dan perencanaan kembali yang merupakan dasar untuk persiapan pemecah masalah. Sampel penelitian ini adalah siswa kelas IV D berjumlah 31 siswa. Aktivitas siswa dalam pembelajaran Matematika dan kemampuan Berpikir Kreatif Matematis siswa setelah penerapan model pembelajaran Creative Problem Solving (CPS) pada pembelajaran Matematika mengalami peningkatan pada setiap siklusnya. Terlihat dari perolehan nilai rata-rata kelas, nilai ketuntasan belajar siswa secara individu, dan Daya Serap Klasikal kelas mengalami peningkatan yang sangat baik pada setiap siklusnya. Pada siklus pertama, nilai rata-rata siswa hanya 66.93 dengan tingkat Daya Serap Klasikal mencapai 51,61\%, kemudian setelah diterapkannya model pembelajaran CPS selama tiga siklus, nilai rata-rata siswa meningkat menjadi 78,23 dengan tingkat Daya Serap klasikal mencapai $87,10 \%$. Hal ini menunjukkan bahwa penerapan model pembelajaran CPS telah berhasil meningkatkan kemampuan berpikir kreatif siswa kelas IV SDIT Cendekia.
\end{abstract}

Kata kunci : Kemampuan Berpikir Kreatif Matematis, Creative Problem Solving.

\section{Abstract}

Problems in mathematics lessons students are less interested in mathematics because mathematics is considered as the most difficult subject among other subjects as well as the students' weak creative thinking abilities in solving mathematical problems. This study aims to determine the effect of using the CREATIVE PROBLEM SOLVING (CPS) model on the mathematical creative thinking ability of fourth grade students at SDIT Cendekia, Purwakarta District, Purwakarta Regency. The research design used was Action Research Class design better known as the spiral selfreflection system that starts from plans, actions, reflection observations and re-planning which is the basis for preparation of problem solvers. The sample of this study was students in class IV D totaling 31 students. Student activities in learning mathematics and students' mathematical creative thinking ability after the application of the Creative Problem Solving (CPS) learning model in learning mathematics has increased in each cycle. It can be seen from the acquisition of the average grade of the class, the value of students' mastery learning individually, and the Classics Absorption power has increased very well in each cycle. In the first cycle, the average value of students was only 66.93 with the level of Classical Absorption reaching 51.61\%, then after the implementation of the CPS learning model for three cycles, the average value of students increased to 78.23 with the classical Absorption level reaching 87, 10\% This shows that the application of the CPS learning model has succeeded in increasing the creative thinking ability of the fourth grade students of SDIT Scholar.

Keywords: Mathematical Creative Thinking Ability, Creative Problem Solving.

@ Jurnal Basicedu Prodi PGSD FIP UPTT 2020

$\triangle$ Corresponding author :

Address :-

Email : :

ISSN 2580-3735 (Media Cetak)

Phone :- 

matematika siswa sekolah dasar-Anggy Giri Prawiyogi, Sri Wulan Anggraeni, Teten Ginanjar Rahayu

\section{PENDAHULUAN}

Berbicara tentang pelajaran Matematika, Peraturan Menteri Pendidikan Nasional No. 22 Tahun 2006 Tentang Standari Isi menegaskan bahwa, "mata pelajaran Matematika perlu diberikan kepada semua siswa mulai dari sekolah dasar untuk membekali siswa dengan kemampuan berpikir logis, analitis, sistematis, kritis, dan kreatif, serta kemampuan bekerjasama." Salah satu kemampuan yang harus dimiliki siswa adalah kemampuan berfikir kreatif matematis. Lestari (2015, hlm. 89) menyatakan bahwa, "kemampuan berfikir kreatif matematis adalah kemampuan untuk menghasilkan ide atau gagasan yang baru dalam menghasilkan suatu cara dalam menyelesaikan masalah." tujuan dalam penelitian ini adalah untuk meningkatkan kemampuan berpikir kreatif matematis siswa dengan menggunakan Model Pembelajaran Creative Problem Solving (CPS).

Namun, berdasarkan hasil observasi awal yang dilakukan oleh peneliti di SDIT Cendekia Purwakarta terhadap guru dan siswa kelas IV, ditemukan beberapa permasalahan, di antaranya: (1) Siswa kurang tertarik terhadap pelajaran matematika karena matematika dianggap sebagai pelajaran yang paling sulit diantara pelajaran yang lainnya. (2) Lemahnya kemampuan berpikir kreatif siswa dalam memecahkan masalah matematika. Hal ini ditunjukkan oleh siswa dalam mengerjakan soal pemecahan masalah matematika. Di mana mereka hanya mengikuti contoh-contoh penyelesaian soal pemecahan masalah yang diberikan guru tanpa bisa mengembangkanya bahkan tidak memiliki ide lain untuk menyelesaikannya. (3) Belum terlihatnya aspekaspek kemampuan berpikir kreatif matematis siswa didik yang seharusnya mereka miliki. Hal ini terlihat dari lemahnya kemampuan siswa dalam menghadapi soal pemecahan masalah matematika. Aspek-aspek kemampuan berpikir kreatif matematis yang belum terlihat pada siswa tersebut, antara lain: siswa tidak lancar menggunakan pengetahuan dan ide yang dimilikinya dalam menghadapi soal pemecahan masalah matematika, memaksakan konsep atau cara penyelesaian yang diberikan guru yang belum benar-benar difahami dan tidak dapat mengubah serta mengembangkannya, siswa tidak terlatih untuk menghasilkan ide atau cara baru dalam menghadapi soal pemecahan masalah matematika, dan lemahnya keterampilan merinci secara detail penyelesaian soal pemecahan masalah matematika. Maka, dapat ditarik sebuah kesimpulan bahwa, siswa memiliki kelemahan dalam memahami masalah dan merencanakan suatu penyelesaiannya secara kreatif.

Setelah mengidentifikasi kelemahankelemahan pada peserta didik di atas, selanjutnya peneliti melakukan diskusi dengan guru kelas untuk mengidentifikasi hal-hal yang menjadi penyebab kelemahan tersebut. Dari hasil diskusi tersebut didapatkan beberapa penyebab di antaranya: (1) proses pembelajaran matematika kurang bervariasi dan cenderung berpusat pada guru atau berlangsung secara teacher center. Maka diperlukan sebuah pembelajaran yang bervariasi, menyenangkan dan melibatkan siswa atau secara student center. (2) siswa hanya menerima konsep dan contoh-contoh dari guru serta kesempatan untuk mengembangkan konsep tersebut sangat kurang. Sehingga siswa tidak terlatih secara khusus bagaimana memahami informasi sebuah masalah. (3) siswa tidak terlatih dalam merencanakan penyelesaian masalah, menyusun strategi-strategi yang bervariasi yang mendorong keterampilan berpikir kreatif untuk menemukan jawaban masalah.

Fakta di lapangan juga dikuatkan oleh hasil ulangan harian yang telah dilaksanakan di kelas IV tersebut. Berdasarkan hasil ulangan harian tersebut, menunjukkan nilai rata-rata kelas 
mencapai 6.28 dengan presentase Daya Serap Klasikal 55\%. Hal ini tentu berbanding terbalik dengan standar yang telah ditetapkan oleh guru kelas tersebut, di mana standar Daya Serap Klasikal yang harus dicapai persentasenya adalah $85 \%$ dari jumlah peserta didik. Sementara itu, ratarata kelas yang dicapai sangat minimal sekali dengan nilai KKM yang telah ditentukan di sekolah tersebut yaitu 70. Dari data tersebut dapat disimpulkan bahwa perlu diadakannya perbaikan dan pengembangan dalam proses pembelajaran.

Untuk mengatasi masalah tersebut, diperlukan sebuah model pembelajaran yang efektif dan menyenangkan yang dapat mengembangkan kemampuan berpikir kreatif matematis peserta didik. Hernawan (2007, hlm.11) mengungkapkan bahwa, "proses pembelajaran akan berjalan dengan baik apabila guru memiliki kemampuan dalam menciptakan suasana pembelajaran yang menyenangkan". Salah satu model pembelajaran yang menyenangkan serta dapat diterapkan dalam pelajaran matematika adalah model pembelajaran Creative Problem Solving (CPS). Lestari (2015, hlm. 65) menuturkan bahwa, "Creative Problem Solving (CPS) merupakan variasi dari pembelajaran penyelesaian masalah dengan teknik yang sistematis dalam mengorganisasikan gagasan kreatif untuk menyelesaikan suatu permasalahan.” Huda (2014, hlm. 298) juga menerangkan bahwa, "guru bertugas untuk menyediakan materi pembelajaran atau topik diskusi yang dapat merangsang siswa untuk berpikir kreatif dalam memecahkan masalah.

\section{METODE}

Penelitian yang dilakukan adalah Penelitian Tindakan Kelas (PTK). Kemmis dan Mc. Taggart (1988) : PTK adalah studi yang dilakukan untuk memperbaiki diri sendiri, pengalaman kerja sendiri yang dilaksanakan secara sistematis, terencana, dan dengan sikap mawas. Jadi Penelitian tindakan kelas merupakan terjemahan dari Classroom Research, yaitu satu action research yang dilakukan oleh guru di dalam kelasnya sendiri melalui refleksi diri, dengan tujuan untuk memperbaiki kinerjanya sebagai guru, sehingga hasil belajar siswa menjadi menjadi meningkat.

Jenis penelitian yang digunakan yaitu penelitian tindakan kelas partisipan. Bentuk penelitian yang digunakan yaitu penelitian tindakan kolaboratif. Sedangkan model yang akan digunakan yaitu Model Kemmis dan Tagart. Hal ini dikarenakan dalam satu siklus terdapat satu tindakan, yaitu penerapan model pembelajaran matematika dengan menggunakan model Creative Problem Solving. Model ini terdiri dari tahap perencaaan, tahapan pelaksanaan, tahap observasi dan tahap refleksi.

Penelitian tindakan kelas ini dilaksanaan di salah satu SD yang berlokasi di Provinsi Jawa Barat, Kabupaten Purwakarta, Kecamatan Purwakarta. Penelitian ini dilakukan selama 2 hari untuk setiap siklusnya, dengan selang waktu satu minggu antara siklus I ke siklus II dan siklus III.

\section{HASIL DAN PEMBAHASAN}

Berdasarkan hasil temuan yang telah dijelaskan pada bagian sebelumnya, untuk mengetahui lebih lanjut mengenai perubahan peningkatan aktivitas siswa dari siklus I ke siklus III dapat dilihat melalui Gambar 1.1 sebagai berikut. 

matematika siswa sekolah dasar-Anggy Giri Prawiyogi, Sri Wulan Anggraeni, Teten Ginanjar Rahayu

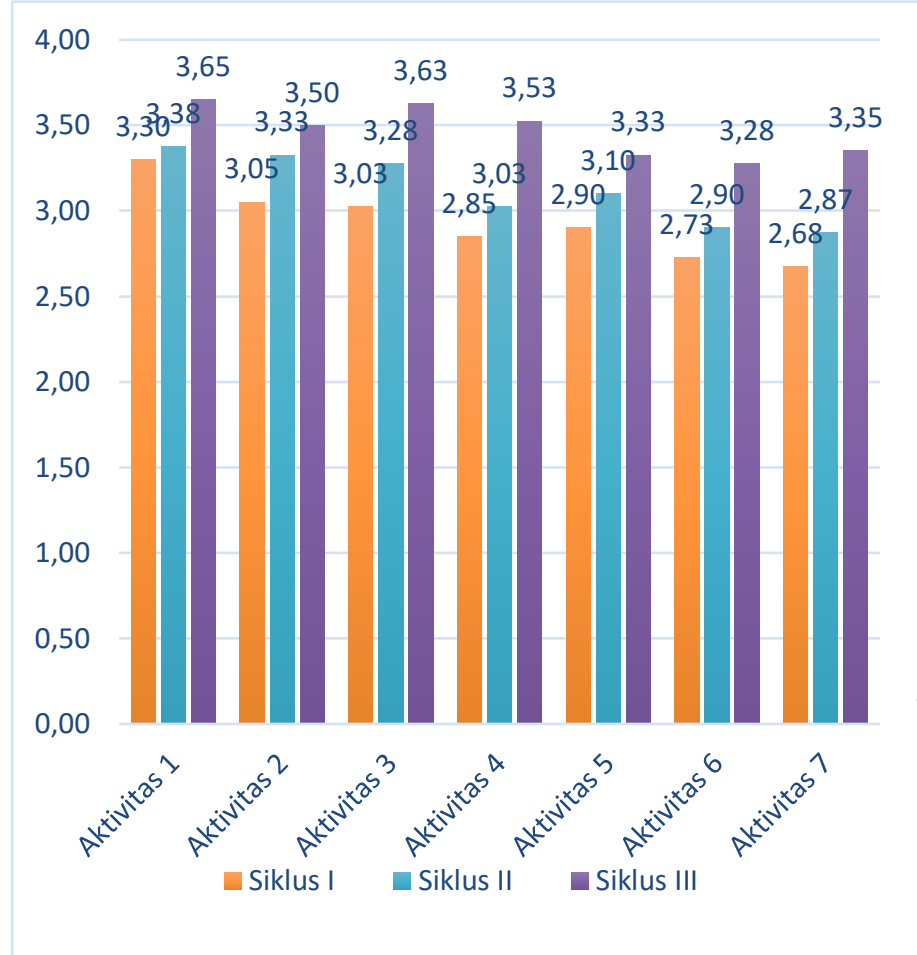

Gambar 1.1

Peningkatan Nilai Rata-rata Aktivitas Siswa Siklus

I, II, dan III

Dari tujuh tahapan ativitas penerapan model CPS yang telah dipaparkan di atas juga dapat dilihat peningkatan aktivitas siswa yang mengalami peningkatan yang signifikan dan stagnan. Peningkatan yang signifikan terjadi pada aktivitas 1 yaitu aktivitas siswa memperhatikan penjelasan guru mengenai masalah yang terdapat pada LKS dimana skor yang ydiperoleh merupakan skro tertinggi yaitu 3.656 dari perolehan skor semua aktivitas siswa pada penerapan model pembelajaran CPS. Sedangkan peningkatan yang paling rendah berada pada aktivitas 6 yaitu aktivitas siswa aktif bertanya dan memberi tanggapan terhadap hasil yang dipresentasikan dengan perolehan skor 3.28 yang merupakan perolehan skor paling rendah di anatara perolehan skor aktivitas yang lainnya. Hal ini terjadi karena masih kurangnya partisipasi siswa dan kurangnya percaya diri siswa untuk bertanya dan memberikan tanggapan kepada guru dan kelompok lain sehingga.
Berdasarkan uraian aktivitas siswa di atas dapat disimpulkan bahwa penerapan model pembelajaran Creative Problem Solving (CPS) berdampak positif dan dapat meningkatkan aktivitas belajar siswa dalam pembelajaran Matematika di kelas IV.

Berdasarkan hasil penelitian tindakan kelas dengan penerapan model pembelajaran Creative Problem Solving (CPS), selain aktivitas siswa dan Aktivitas guru yang diamati, dalam penelitian ini juga meneliti hasil tes Kemampuan Berpikir Kreatif Matematis siswa. Berdasarkan data hasil aktivitas siswa pada pelaksanaan siklus I, II, dan Siklus II terjadi peningkatan yang cukup baik dan signifikan, sehingga peningkatan ini juga berbanding lurus dengan hasil tes Kemampuan Berpikir Kreatif Matematis siswa. Adapun data nilai rata-rata Kemampuan Berpikir Kreatif Matematis siswa dapat dilihat pada Tabel 1.2.

Tabel 1

Hasil Kemampuan Berpikir Kreatif Matematis Siswa Siklus I, II, dan III

\begin{tabular}{|l|l|l|l|}
\hline No & Siklus & $\begin{array}{l}\text { Rata- } \\
\text { rata }\end{array}$ & $\begin{array}{l}\text { Daya Serap } \\
\text { Klasikal }\end{array}$ \\
\hline 1 & I & 66,93 & $51,61 \%$ \\
\hline 2 & II & 74,67 & $67,74 \%$ \\
\hline 3 & III & 78,23 & $87,10 \%$ \\
\hline $\begin{array}{l}\text { Peningkatan } \\
\text { Siklus I ke II }\end{array}$ & 7,74 & $16.13 \%$ \\
\hline $\begin{array}{l}\text { Peningkatan } \\
\text { Siklus II ke III }\end{array}$ & 3,56 & $19,36 \%$ \\
\hline
\end{tabular}

Pada siklus I nilai rata-rata yang diperoleh sebesar 66.93, nilai ini belum mencapai batas kriteria ketuntasan minimal yaitu $\geq 70$ yang telah ditetapkan oleh SDIT Cendekia. Di sisi lain Daya Serap Klasikal (DSK) yang diperoleh hanya sebesar $51,61 \%$, dengan kata lain masih terdapat cukup banyak siswa yang belum mencapai batas Daya Serap Klasikal yang telah ditentukan yaitu $\geq$ 
85\%. Hal ini disebabkan karena siswa masih belum terbiasa dengan rentetan kegiatan pembelajaran dengan menggunakan model Creative Problem Solving (CPS). Sehingga berdampak besar pada hasil tes pemahaman siswa terkait materi pembelajaran yang masih belum maksimal. Dalam upaya meningkatkan persentase ketuntasan belajar supaya menjadi $\geq 85 \%$, tentunya diperlukan perbaikan dan refleksi dalam melaksanakan pembelajaran pada siklus selanjutnya.

Setelah kegiatan tindakan refleksi untuk pelaksanaan tindakan siklus II, dapat terlihat perubahan yang terjadi antara ketuntasan belajar siswa siklus I terhadap siklus II, hal ini tercermin dari nilai rata-rata pada siklus II yang meningkat menjadi 74,67 dan DSK yang diperoleh juga sudah mencapai $67,74 \%$. Peningkatan hasil aktivitas siswa dan Aktivitas guru pada siklus II berbanding lurus dengan hasil tes Kemampuan Berpikir Kreatif Matematis siswa, pencapaian Daya Serap Klasikal belum mencapai kriteria yang telah ditentukn yang harusnya $>85$. Berdasarkan hal tersebut diperlukan perbaikan dan refleksi dalam melaksanakan pembelajaran pada siklus selanjutnya yaitu di Siklus III.

Setelah kegiatan tindakan refleksi untuk pelaksanaan tindakan siklus III, dapat terlihat kembali sebuah perubahan yang terjadi antara ketuntasan belajar siswa siklus II terhadap siklus III, hal ini tercermin dari nilai rata-rata pada siklus III yang meningkat menjadi 78.23 dan DSK yang diperoleh juga sudah mencapai $87,10 \%$. Peningkatan hasil aktivitas siswa dan Aktivitas guru pada siklus III berbanding lurus dengan hasil tes Kemampuan Berpikir Kreatif Matematis siswa, pencapaian Daya Serap Klasikal sudah mencapai kriteria yang telah ditentukn yaitu $>85$. Hal tersebut terjadi karena adanya upaya perbaikan dan refleksi pada setiap siklusnya.
Evaluasi dan perbaikan tersebut dimulai dari pemfokusan pada tahapan pembelajaran Creative Problem Solving (CPS) yang pelaksanaannya masih belum maksimal pada siklus I. Maka pada siklus II difokuskan pada peningkatan kategori yang masih belum maksimal tersebut, sehingga pembelajaran menjadi lebih baik pada siklus II. Tidak cukup di siklus II, pembelajaran masih perlu perbaikan kembali karena penilaian aktivitas siswa, guru, dan hasil evaluasi masih belum maksimal. Maka dilakukan kembali perbaikan dan tindakan pada siklus ke III dengan menggunakan model Creative Problem Solving (CPS) lebih terpusat pada aktivitas siswa.

\section{SIMPULAN}

Peningkatan tersebut tentunya dipengaruhi dengan pemilihan model pembelajaran yang tepat. Melalui penerapan model pembelajaran Creative Problem Solving (CPS), aktivitas siswa dalam belajar menjadi lebih meningkat dan dapat meningkatkan hasil belajar siswa khususnya kemampuan berpikir kreatif matematis siswa. Hal ini terbukti dari berbagai aspek yang peniliti amati, mulai dari aktivitas siswa, aktivitas guru, tes kemampuan berpikir kreatif matematis, semua aspek tersebut memperoleh peningkatan yang positif sesuai apa yang telah dipaparkan sebelumnya.

\section{DAFTAR PUSTAKA}

Arikunto,Suharsimi. (2012). Dasar-Dasar Evaluasi Pendidikan Edisi 2. Jakarta: PT.Bumi Aksara.

Arikunto, Suharsimi. (2013. Prosedur Penelitian Suatu Pendekatan Praktik. Jakarta: Rineka Cipta.

Burhanuddin,(2007).Pendekatan, Metode, dan

Teknik Penelitian. Purwakarta: Program Pendidikan Guru Sekolah Dasar Universitas Pendidikan Indonesia Kampus Purwakarta. 

matematika siswa sekolah dasar-Anggy Giri Prawiyogi, Sri Wulan Anggraeni, Teten Ginanjar Rahayu

Chamisijatin, dkk. (2008). Pengembangan Kurikulum SD 3 SKS. Direktorat Jenderal Pendidikan Tinggi: Departemen Pendidikan Nasional.

Hendriana, Heris dan Utari Soemarmo. (2014) Penilaian Pembelajaran Matematika. Bandung: PT. Refika Aditama.

Hermawan, Asep Herry, dkk. 2007. Pengembangan Kurikulum dan Pembelajaran.

Heruman. (2012). Model Pembelajaran Matematika di Sekolah Dasar. Bandung: PT. Remaja Rosdakarya.

Huda, Miftahul. (2014). Model-Model Pengajaran dan Pembelajaran Isu-Isu Metodis Pradigmatis. Yogyakarta: Pustaka Pelajar

Isaksen, S.G. (2013) Facilitating Creative Problem-Solving Groups. [ONLINE] Tersedia di

http://www.cpsb.com/research/articles/creative -problem-solving/Facilitating-CPS-

Groups.html. [15 Desember 2016]

Lestari Eka Karunia dan Yudhanegara. (2015).

Penelitian Pendidikan Matematika. Badung: Refika Aditama

Nurlaela, Luthfiyah dan Euis Ismayanti. (2015). Strategi Belajar Berpikir Kreatif. Yogyakarta: Penerbit Ombak Dua

Peraturan Menteri Pendidikan Nasional No. 22 Tahun 2006

Purwanto, N. M. (2008). Psikologi Pendidikan. Bandung: PT. Remaja Rosdakarya

Shoimin, (2014). 68 Pembelajaran Inovatif dalam Kurikulum 2013. Yogyakarta: Ar-ruz Media
Sumarmi, Mas Titing dan Siti Kamsiyati. (2009). Asyiknya Belajar Matematika untuk SD/MI kelas IV. Jakaarta: Pusat Perbukuan Nasional

Slavin Robert E. (2005). Cooperative Learning: Theory, Research and Practice. London: Allymand Bacon (terjemahan bahasa indonesia)

Supinah \& D.W. (2009). Suplemen Matematika Bermutu. Departemen Pendidikan Nasional Direktorat Jenderal Peningkatan Mutu Pendidik dan Tenaga Kependidikan: Pusat Pengembangan dan Pemberdayaan Pendidik dan Tenaga Kependidikan (PPPPTK) Matematika 2009

Siswono, Tatag Y.E. (2005). Upaya Meningkatkan Kemampuan Berpikir Kreatif Siswa Melalui Pengajuan Masalah. [ONLINE] Tersedia di https://tatagyes.files.wordpress.com/2009/11/p aper05_problemposing.pdf. [22 Desember 2016]

Trianto, (2012). Panduan lengkap Penelitian Tindakan Kelas (Classroom Action Research) TEORI \& PRAKTIK. Jakarta: Prestasi Pustakaraya.. 